УДК 340.11

\author{
Г. О. Дубов, \\ кандидат юридичних наук, асистент кафедри \\ теорії права та держави Київського начіонального \\ університету імені Тараса Шевченка
}

\title{
ДОСЛІДЖЕННЯ ЮРИДИЧНОЇ МЕТОДОЛОГІї У ПЕРІОД ВИНИКНЕННЯ ТА СТАНОВЛЕННЯ ЮРИДИЧНОЇ НАУКИ НЕЗАЛЕЖНОЇ УКРАЇНИ
}

Постановка проблеми. Необхідність комплексної, системної розробки методів правової науки, вказівки на недостатню інтенсивність обговорення методологічних питань серед вчених-юристів наголошується, починаючи із 60-х років XX століття. Однак це завдання вважалося не реалізованим як станом на 1980 рік, так і на початку 1990-х років. Сучасний стан методологічного доробку української юридичної науки нерідко характеризується вченими-юристами у зв'язку із відсутністю чіткого окреслення проблематики та концептуальної побудови методологічних досліджень.

Актуальність дослідження розвитку вивчення питань методології сучасної української юридичної науки у період іiї виникнення та становлення полягає в тому, що спеціальних досліджень 3 цієї проблеми, на відміну від досліджень наукової спадщини дореволюційної доби, проводилось недостатньо, незважаючи на їх важливість, а також необхідність окремого осмислення динамічного аспекту еволюції методології юридичної науки

Аналіз останніх досліджень та публікацій. Порушеним у статті питанням було присвячено увагу таких вчених юристів, як Ф. Г. Бурчак, Ю. М. Грошевий, І. М. Дальшин, В. С. Зеленський, М. І. Козюбра, В. В. Копєйчиков, М. І. Панов, П. М. Рабінович, В. Я. Тацій, Ю. М. Тодика, М. В. Цвік, Ю. С. Шемшученко.

Метою статті $\epsilon$ встановлення закономірностей розвитку досліджень юридичної методології у період виникнення та становлення юридичної науки незалежної України

Основні результати дослідження. Розглядуваний етап у розвитку вітчизняної юридичної науки взагалі та методологічних досліджень зокрема, пов'язується зі здобуттям Україною незалежності. Зникнення із політичної мапи світу СРСР, поява на його територіях нових незалежних держав, які у своїй більшості прагнули до розвитку на основі інших цінностей та ідеології, обумовили величезні за своїми масштабами трансформаційні процеси у політичній, ідеологічній, економічній, соціальній та міжнародній сферах життя пострадянських суспільств.

Такі всеохоплюючі суспільно-політичні зміни не могли не вплинути на вітчизняне правознавство загалом та методологію пізнання юридичних явищ зокрема, адже, як зазначав відомий філософ науки Т. Кун, раціональна основа в такій науці, як юриспруденція, забезпечена саме соціальною необхідністю [8, с. 15].

Слід погодитися також із думкою Е. А. Позднякова, відповідно до якої саме обвальний крах радянської соціальної системи потягнув за собою такий же масштабний крах і методологічної основи суспільних наук, яка втратила багато із своїх орієнтирів [10, с. 21]. У цьому відношенні початок сучасного етапу розвитку юридичної науки, будучи пов'язаним із необхідністю перебудови ії основ, $€$ вельми подібним до часу формування радянської юридичної науки.

Як і в часи жовтневої революції, нові виклики, які постали перед українським суспільством після надбання власної державності, знайшли безпосереднє відображення в межах правознавства, актуалізуючи нові проблеми та продукуючи їі якісні перетворення. При цьому саме рівень розробленості методологічних питань визнавався одним із фундаментальних показників рівня розвитку вітчизняного правознавства та правової культури суспільства [13, с. 16].

Найпомітніші зміни на початку 90 -х років XX століття в умовах набуття Україною власної державності відбулися у політичній сфері життя українського суспільства. Однією із найважливіших із них прийнято вважати скасування інституту загальнообов'язкової державної ідеології, безпосереднім наслідком якого постало виникнення політичного та ідеологічного плюралізму. 
Дубов Г. О. Дослідження юридичної методології у період виникнення та становлення юридичної науки...

Саме конкуренція між представниками всього можливого спектра політичних поглядів та ідеологічних установок, ставши реальним суспільно-політичним фактором одразу після здобуття Україною незалежності, суттєво вплинула на правознавство, яке, за висловом М. І. Козюбри, в радянський період було однією із найбільш заідеологізованих серед наук [6, с. 3]. Із впровадженням у суспільну практику принципів політичного та ідеологічного плюралізму моністичність філософських основ вітчизняної юридичної науки мала бути переглянута, що й обумовило підвищений інтерес до цього питання з боку вчених-юристів.

Не меншого значення для розвитку методологічних досліджень у юридичній науці мали трансформаційні процеси в економічній сфері, потреби розвитку якої, на думку багатьох вітчизняних учених-юристів, були «квінтесенцією» суспільних потреб [12, с. 39] та мали стати одним із головних орієнтирів розвитку вітчизняного правознавства, критерієм його методологічної обгрунтованості [15, с. 37].

Саме необхідність приведення методології правових досліджень у відповідність новому етапу становлення національного права, пов'язаного із початком формування в Україні ринкових відносин [5, с. 7], визнавалася одним із основних факторів, дія якого об'єктивно викликала потребу у реформуванні методології правових досліджень. Саме за умов реформування економічної системи виразно проявляється необхідність переорієнтації юридичної науки та досліджень методологічних питань на нові суспільні ідеали та цінності. Нагальна потреба в оновленні методологічної складової вітчизняної юридичної науки в аспекті трансформацій системи економічних відносин випливала безпосередньо із тези про несумісність методологічних засад правознавства так званих буржуазних держав та держав соціалістичного табору, яка обгрунтовувалася в межах радянської юридичної науки. У цьому контексті, зокрема, позиція щодо необхідності опрацювання найбільш загальних питань правової методології «в річищі ліберальної традиції» [9, с. 6] виявилася досить поширеною.

Аналогічних за масштабами економічної системи перетворень зазнала й гуманітарна сфера життя українського суспільства, так само характеризуючись передусім утвердженням нових суспільних ідеалів та цінностей, стратегічною метою якого вважалася гуманізація усіх сфер суспільного життя [12, с. 39]. Цей фактор, на думку В. Я. Тація, обумовив необхідність переходу української юридичної науки до нових методологічних орієнтирів [16, с. 4].

Окремо слід також виділити актуалізацію можливостей збагачення методології держави і права ідеями та положеннями, виробленими світовою філософією та юриспруденцією, яка постала наслідком змін у міжнародній сфері, відкриття «залізної завіси» як в сенсі запровадження свободи пересування, так і у відношенні дезавуювання низки ідеологічних перепон, що стримували можливості імплементації досягнень світової науки у вітчизняне правознавство.

Помітною тенденцією розвитку методологічних досліджень на початку 90-х років XX століття $\epsilon$ наголошення на його пов'язаності із практичними потребами державного будівництва. Недостатність знання закономірностей пізнання суспільних відносин, що змінили свою якість в умовах незалежності, вважалася однією із найважливіших причин малої ефективності регулювання їх окремих сфер, що спостерігалася на початках існування України як незалежної держави [5, с.116]. Саме пізнання права в нових умовах визнавалося основною умовою його реалізації [5, с. 262].

Така практична орієнтація вчених-юристів породила дещо парадоксальну особливість розвитку методологічних досліджень. Адже, з одного боку, обумовлений описаними вище суспільно-політичними факторами, стан, в якому опинилося українське суспільство, послугував потужним стимулом до якісних перетворень у сфері правової методології, а з іншого - виступив чинником, який стримував ії розвиток.

Надзвичайно розповсюдженою позицією в роботах багатьох теоретиків юриспруденції розглядуваного періоду стало посилання на те, що у зв'язку із складною соціально-політичною ситуацією вирішення окремих проблем правового регулювання суспільних відносин мало бути визнано пріоритетним. При цьому теоретичні суперечки про методи та принципи дослідження оголошувалися не надто важливими і такими, що можуть бути відкладені до «кращих часів» [3, с. 4]. За такої ситуації один із «принципів» проведення юридичних досліджень оформлювався тезою «менше академізму, більше прагматизму» [14, с.18].

Із цієї причини стан досліджень методологічних питань характеризувався у роботах науковців 1990-х років не інакше як кризовий $[5$, с. 6], а здійснювані теоретичні узагальнення як такі, що обмежувалися рамками повсякденного «здорового глузду» [14, с.19]. 
Незважаючи на усвідомлення вітчизняними науковцями значущості фундаментальних теоретичних досліджень для вирішення в тому числі суто прикладних питань [5, с.116], стрімкий характер подій, які викликали необхідність перегляду основ юридичної науки, для переходу від констатації нагальної необхідності якнайшвидшого провадження новітніх методологічних досліджень до хоча б реального окреслення їх шляхів українським ученим-юристам знадобилося чимало часу.

Свідченням неквапливого характеру перебудови методології юридичних наук може послугувати те, що станом на кінець 1996 року провідними українськими дослідниками була констатована повна відсутність провадження монографічних праць безпосередньо із методологічних проблем права, наукових структур та колективів для їх спеціального опрацювання [11, с.150], недостатня інтенсивність обговорення методологічних питань юридичної науки серед вчених-юристів [9, с. 3].

За висловом Л. В. Петрової, через п'ять років після здобуття Україною незалежності багато авторитетних українських правників були одностайні у тому, що розробка методологічних засад лише започатковувалась [9, с. 4].

Задля справедливості варто відзначити, що така вада не була характерною виключно для вітчизняного правознавства. Подібна ситуація спостерігалася у юридичних науках більшості пострадянських країн. Наприклад, описуючи ситуацію у правознавстві Російської Федерації станом на 1997 рік, відомий вчений-юрист Д. А. Керімов характеризував іїі як стан глибокого занепаду. Так само, як і українські вчені, відзначав фактичне зникнення фундаментальних правових досліджень та зосередження уваги науковців на дослідженні прикладних, приватних питань або «поганому коментуванні поганого законодавства» чи «безпорадному узагальненню безпорадної правозастосовної практики» [4, с. 3].

Звичайно, особливості ситуації в Україні початку 90-х років XX століття, що характеризувалася значною кількістю соціальних та політичних проблем, які постали перед суспільством, не могли створити належні умови для провадження фундаментальних досліджень права, до яких слід віднести питання методології юридичних досліджень. Першочерговим завданням в той час юристи визначали перебудову правової системи під нові потреби, обумовлені кардинальною зміною принципів існування політичної, економічної та гуманітарної систем суспільства. Необхідність такого реформування при цьому визнавалася нагальною та невідкладною [14, с. 21], що й спрямовувало діяльність науковців, зосереджуючи їх увагу на проблематиці, що мала безпосередній та швидкий вихід в практичну площину. У зв'язку з цим саме інформаційнометодична та коментаторська функції в цей час називалися головними для юридичної науки незалежної України [7, с 13].

Поряд із відсутністю належних організаційних умов та відсутністю соціальних запитів на дослідження високого теоретичного рівня, неквапливість просування методологічних досліджень можна пояснити і суто внутрішньонауковими причинами. Адже після відступу від тотального використання моноідеології радянського суспільства у трактуванні процесів та явищ державно-правової дійсності виникла ситуація, за якої пояснювальні схеми, що приймалося раніше, були поставлені під сумнів, проте їм на зміну одразу не прийшли якісь нові, кращі, більш глибоко обгрунтовані. У зв'язку з цим в юридичній літературі початку 1990-х років можна зустріти таку характеристику юридичної теорії як «кашоподібність» [2, с.12-14] у значенні практично суцільної невизначеності з ключових питань.

Загалом таку ситуацію слід визнати закономірною, погодившись із думкою А. А. Козловського, який вважає, що вивчення методів більш притаманно етапам «стабільного» розвитку знання, коли воно потребує покращення в рамках певної парадигми, а також свого структурування [5, с. 8].

Вивчення правової методології за радянських часів $є$ надзвичайно показовими у цьому відношенні, адже на самих ранніх періодах їх розвитку більшість робіт учених-юристів мали суто прикладну спрямованість та стосувалися окремих конкретних питань застосування чинного на той час законодавства [1, с. 22-23]. I лише після того як радянським науковцям вдалося знайти вирішення ключових філософських та ідеологічних питань, сформувати основи радянської юридичної науки, методологія дослідження держави і права почала обгрунтовуватися та реалізовуватися.

Періоди фундаментальних перетворень основ науки із необхідністю не сприяють грунтовним дослідженням методологічної проблематики, оскільки на цьому етапі розвитку знання першочерговими питаннями постають питання пошуку нових світоглядних, ціннісних та ідеологічних орієнтирів, формування основ науки. 
Висновки. Враховуючи викладене, період із 1991 по 1996 роки у вітчизняній юридичній науці, незважаючи на декларування важливості методологічної проблематики, характеризувався відсутністю іï реального розроблення. В цей час було актуалізовано такі напрямки розвитку методологічних досліджень, як необхідність перегляду світоглядно-філософських основ вітчизняного правознавства, його відходу від позицій методологічного монізму, забезпечення засобами юридичної науки потреб розвитку економічної системи України у процесі ії переходу на ринкові засади.

\section{Список використаних джерел}

1. Бабий Б. М. Очерк развития правовых исследований в Украинской ССР 1919-1984 гг. / Б. М. Бабий - К. : Наук. думка, 1984. - 196 с.

2. Бутенко А. П. Государство: его вчерашние и сегодняшние трактовки // Государство и право. - 1993. - №7. C. $12-14$.

3. Демидов А. И. О методологической ситуации в правоведении / А. И. Демидов // Правоведение. - 2001. - № 4. C.14-22.

4. Керимов Д. А. Потенциал российского правоведения / Д. А. Керимов // Социологические исследования. 1997. - № 3. - С. 3-13.

5. Козловський А. А. Право як пізнання: вступ до гносеології права / А. А. Козловський. - Чернівці : Рута, 1999. $295 \mathrm{c}$.

6. Козюбра M. I. Проблеми методології теорії держави і права в умовах політичного та ідеологічного плюралізму / М. І. Козюбра // Проблеми правознавства. - К. - 1992. - № 53. - С. 3-8.

7. Костицький М. В. Філософсько-правові питання методології юридичної науки / М. В. Костицький // Філософські та методологічні проблеми права №2. - 2011. - С. 13-27.

8. Кун Т. Структура научных революцій : пер. с англ. Налетова И. 3. - М., Прогресс, 1975. - 288 с.

9. Петрова Л. В. Фундаментальні проблеми методології права : автореф. дис. ... д-ра юрид. наук : 12.00 .12 / Л. В. Петрова. - Х., 1998. - 36 с.

10. Поздняков Э. А. Философия государства и права. - М.1995. - 312 с.

11. Проблеми методології сучасного правознавства // Вісник Академії правових наук України. - 1997. - № 1. C. $143-150$.

12. Рабінович П. М. Методологія вітчизняного загальнотеоретичного праводержавознавства: сучасні тенденції / П. М. Рабінович // Бюлетень Міністерства юстиції України. - 2003. - №1 . - С. 37-45.

13. Селіванов В. М. До проблеми розроблення концепції розвитку вітчизняної юридичної науки / В. М. Селіванов // Право України. - 2001. - № 7. - С. 11-18.

14. Селіванов В. М., Цвєтков В. В. Від здорового глузду до теорії державного управління / В. М.Селіванов, Цвєтков В. В. // Право України. - 2001. - № 5. - С. 18-23.

15. Селіванов В. М. Проблема методологічної обгрунтованості вітчизняного правознавства та юридичної практики / В. М. Селіванов // Право України. - 1998. - № 12. - С. 34-43.

16. Тацій В. Я. Методологічні проблеми правової науки на етапі формування правової, демократичної, соціальної держави / В. Я. Тацій // Методологічні проблеми правової науки. Матеріали міжнародної наукової конференції. Харків, 13-14 грудня 2002 р. / Упорядники М. І. Панов, Ю. М. Грошевий. - Х. : Право, 2003. - С. 4-25.

Дубов Г. О. Дослідження юридичної методології у період виникнення та становлення юридичної науки незалежної України

У статті розглянуто перший період сучасного етапу розвитку досліджень юридичної методології. Зроблено висновок, що методологічні дослідження розглядуваного періоду характеризуються актуалізацією питань перегляду світоглядно-філософських основ вітчизняного правознавства, його відходу від позицій методологічного монізму, запровадження нових ціннісних орієнтирів, забезпечення засобами юридичної науки потреб розвитку економічної системи України у процесі їі переходу на ринкові засади. Втім, незважаючи на декларування важливості методологічної проблематики, цей період в цілому характеризується відсутністю ії комплексного розроблення. Встановлено, що наведена ситуація пов'язана із тим, що періоди фундаментальних перетворень основ науки із необхідністю не сприяють грунтовним дослідженням методологічної проблематики, оскільки на цьому етапі розвитку знання першочерговими питаннями постають питання пошуку нових світоглядних, ціннісних та ідеологічних орієнтирів, формування основ науки.

Ключові слова: методологія, юридичні дослідження, методологічний плюралізм, основи науки.

Dubov G. O. Study of legal methodology in the period of the emergence and formation of the legal science of independent Ukraine

The article is dedicated to the first period of the modern stage of the development of research in legal methodology. It is concluded that the methodological research of the period under review is characterized by actualization of the issues 
of revision of philosophical fundamentals of domestic jurisprudence, its departure from the positions of methodological monism, the introduction of new values, and the provision of legal science with the needs of the development of the economic system of Ukraine in the process of its transition to market principles. However, despite the declaration of the importance of methodological issues, this period as a whole is characterized by the lack of its integrated development. It is established that the given situation is connected with the fact that the periods of fundamental transformations of the fundamentals of science under the necessity do not contribute to a thorough research of methodological issues, since at this stage of development of knowledge the first questions arise the search for new ideological, value and ideological guidelines, the formation of the foundations of science.

Key words: methodology, legal research, methodological pluralism, basis of science.

DOI: 10.33.66.3/2524-017X-2019-10-128-132

УДК 340

\author{
Світлана Евгенівна Камаралі, \\ дочент кафедри теорії, історії права і держави \\ та конституиійного права Університету державноі \\ фіскальної служби України, кандидат історичних наук, дочент
}

Дмитро Анатолійович Шевченко,

заступник начальника відділу поліції з обслуговування житлового масиву «Виноградар» Подільського управління полічї ГУНП в м. Києві, кандидат юридичних наук

\title{
ТОРГОВЕЛЬНА ПОЛІТИКА УРЯДУ ПАВЛА СКОРОПАДСЬКОГО: ІСТОРИКО-ПРАВОВИЙ МОНІТОРИНГ
}

Постановка проблеми. В умовах докорінного реформування українського суспільства перед Україною постала низка завдань, у першу чергу, економічних, при вирішенні яких необхідно спиратись як на світовий, так і на вітчизняний досвід. Дослідженння організаційно-правових основ фінансово-економічної діяльності в часи перебування Української Держави актуальне для подолання проблем становлення національної економіки, торгівлі, побудови тривкої фінансової системи. Їх творче використання може стати ефективним при виробленні засад сучасної господарчої політики.

Мета статті. Метою статті є аналіз організаційно-правових основ діяльності уряду гетьмана П. Скоропадського в галузі внутрішньої торгівлі; визначення пріоритетних векторів фінансово-економічної політики в період кризи державотворення.

Аналіз останніх досліджень та публікацій. Сучасний стан досліджень цієї проблематики окреслено в працях І. Бойка, П. Гая-Нижника, Я. Грицака, Т. Гунчака, О. А. Коцура, О. Красівського, М. Кугутяка, В. Кульчицького, Р. Матейка, В. Піскуна, О. Реєнта, Б. Савчука, М. Сеньківа, О. Субтельного, М. Творидла, І. Терлюка, Б. Тищика, Ю. Тлущака та ін.

Основні результати дослідження. Основним зв'язком між сферами виробництва і споживання, грунтовною підвалиною всякого економічного будівництва виступає торгівля. Перша світова війна істотно вплинула на їі розвиток. Через переведення багатьох підприємств на військові замовлення торгові зв'язки руйнувалися. Внутрішня торгівля приймала все більше натуралізований характер обміну. Ярмаркова діяльність поступово згасала. А постійні розподіли українських земель між військовими сторонами виключали будь-яку можливість торговельних зв'язків. Після розпаду Російської імперії економічні стосунки між ії регіонами були розірвані. Отримали розповсюдження базари, де розквітла спекуляція. Внаслідок інфляції гроші втратили довіру, перевага віддавалася обміну товарами. Біржі припинили своє існування. Через нестачу харчових продуктів, різкого зниження покупної спроможності населення магазини, ресторани збанкрутіли, а інші були пограбовані за часи революційних подій.

Гетьманському уряду у спадщину залишилася скинута майже до феодального рівня торгівля. Спираючись на підприємців і торговельників, гетьман П. Скоропадський поновив приватну влас- 